\title{
LINE-1 Endonuclease-Dependent Retrotranspositional Events Causing Human Genetic Disease: Mutation Detection Bias and Multiple Mechanisms of Target Gene Disruption
}

\author{
Jian-Min Chen, ${ }^{1,2,3}$ Claude Férec, $^{1,2,3,4}$ and David N. Cooper ${ }^{5}$ \\ ${ }^{1}$ INSERM U613, Génétique Moléculaire et Génétique Épidémiologique, 29220 Brest, France \\ ${ }^{2}$ Faculté de Médecine de Brest et des Sciences de la Santé, Université de Bretagne Occidentale, 29238 Brest, France \\ ${ }^{3}$ Etablissement Français du Sang-Bretagne, 35000 Rennes, France \\ ${ }^{4}$ Hôpital Morvan, CHRU Brest, Laboratoire de Génétique Moléculaire et d'Histocompatibilité, 29200 Brest, France \\ ${ }^{5}$ Institute of Medical Genetics, School of Medicine, Cardiff University, Heath Park Campus, Cardiff CF14 4XN, UK
}

Received 20 April 2005; Revised 11 October 2005; Accepted 13 October 2005

\begin{abstract}
LINE-1 (L1) elements are the most abundant autonomous non-LTR retrotransposons in the human genome. Having recently performed a meta-analysis of L1 endonuclease-mediated retrotranspositional events causing human genetic disease, we have extended this study by focusing on two key issues, namely, mutation detection bias and the multiplicity of mechanisms of target gene disruption. Our analysis suggests that whereas an ascertainment bias may have generally militated against the detection of autosomal L1-mediated insertions, autosomal L1 direct insertions could have been disproportionately overlooked owing to their unusually large size. Our analysis has also indicated that the mechanisms underlying the functional disruption of target genes by L1-mediated retrotranspositional events are likely to be dependent on several different factors such as the type of insertion (L1 direct, L1 trans-driven Alu, or SVA), the precise locations of the inserted sequences within the target gene regions, the length of the inserted sequences, and possibly also their orientation.
\end{abstract}

Copyright (c) 2006 Jian-Min Chen et al. This is an open access article distributed under the Creative Commons Attribution License, which permits unrestricted use, distribution, and reproduction in any medium, provided the original work is properly cited.

\section{INTRODUCTION}

LINE-1 (long interspersed element-1) or L1 elements account for $\sim 17 \%$ of the human genome sequence [1]. However, of $>500,000$ L1 copies, only $\sim 80-100$ are capable of active retrotransposition [2]. Retrotranspositionally competent L1 elements are typically $6.0 \mathrm{~kb}$ in length and L1 retrotransposition is thought to occur by target-site-primed reverse transcription [3-5]. Apart from simple self-insertion, L1 retrotransposition can alter the primary structure of the human genome in a variety of different ways $(6,7,8,9)$.

Recently, we performed a comprehensive meta-analysis of $48 \mathrm{~L} 1$ endonuclease-mediated retrotranspositional events that cause human genetic disease. This analysis explored the sequence features associated with the different L1-mediated human retrotransposons (ie, L1 direct insertions, L1 transdriven Alu insertions, and L1 trans-driven SVA (short interspersed nucleotide elements- $\mathrm{R}$, variable number of tandem repeats, and Alu insertions)), the frequency of genomic deletions created upon L1-mediated retrotransposition, and the process of L1-mediated insertion [6]. Here, we have extended this analysis by focusing on two key issues namely, mutation detection bias and the multiple mechanisms of target gene disruption. Note that during the preparation of this review, three further examples of simple Alu insertions causing human disease have been reported; these were also included in the analysis (Table 1).

\section{MUTATION DETECTION DISPLAYS A SIGNIFICANT BIAS}

Since the first report that de novo L1 insertions into the factor VIII gene (F8) had caused severe haemophilia A [7], numerous examples of simple L1-mediated retrotranspositional events (ie, those involving no loss of target gene material; $n=42$ ) have been identified as a cause of human genetic disease (Table 1). Based upon results from in vitro studies $[8,9]$, we have systematically annotated disease-causing 
TABLe 1: L1 endonuclease-mediated retrotranspositional events known to cause human genetic disease.*

\begin{tabular}{|c|c|c|c|c|c|c|c|c|}
\hline $\begin{array}{l}\text { Disrupted } \\
\text { gene }\end{array}$ & $\begin{array}{l}\text { Chrom. } \\
\text { location }\end{array}$ & $\begin{array}{l}\text { Inserted } \\
\text { element }\end{array}$ & $\begin{array}{l}\text { Insertion size } \\
\text { (bp)/orientation }{ }^{\mathrm{a}}\end{array}$ & $\begin{array}{l}\text { Length of } \\
\text { poly (A) } \\
\text { tail (bp) }\end{array}$ & $\begin{array}{c}\text { Location of insert } \\
\text { within the target } \\
\text { gene }^{b}\end{array}$ & $\begin{array}{l}\text { Target gene } \\
\text { disruption }^{\mathrm{c}}\end{array}$ & $\begin{array}{l}\text { Original detection } \\
\text { method }^{\mathrm{d}}\end{array}$ & Reference \\
\hline \multicolumn{9}{|c|}{ Simple insertions } \\
\hline$A P C$ & $5 q$ & L1 Ta & $520 / \mathrm{S}$ & 222 & E15 & $-^{\mathrm{e}}$ & Southern blotting & {$[56]$} \\
\hline $\mathrm{CHM}$ & $\mathrm{Xq}$ & $\mathrm{L} 1 \mathrm{Ta}$ & 6017/AS & 71 & E6 $(+35 ;-82)$ & Skipping of E6 & $\begin{array}{l}\text { Initially failed to } \\
\text { amplify exon } 6\end{array}$ & {$[22]$} \\
\hline$C Y B B$ & $\mathrm{Xp}$ & L1 Ta & $836 / \mathrm{S}$ & 69 & I5 (+1864; -278) & Complex splicing & RT-PCR & {$[23]$} \\
\hline$C Y B B$ & $\mathrm{Xp}$ & L1 Ta & $1722 / \mathrm{S}$ & 101 & $\mathrm{E} 4$ & - & Southern blotting & {$[57]$} \\
\hline$D M D$ & $\mathrm{Xp}$ & $\mathrm{L} 1 \mathrm{Ta}$ & $1400 / \mathrm{S}$ & 38 & $\mathrm{E} 48$ & - & Southern blotting & {$[58]$} \\
\hline$D M D$ & $\mathrm{Xp}$ & L1 Ta & 530/AS & 73 & $\begin{array}{l}\text { 5'-UTR } \\
\text { (see text) }\end{array}$ & $\begin{array}{c}\text { No expression of } \\
\text { muscle form } \\
\text { transcript }\end{array}$ & RT-PCR & {$[45]$} \\
\hline$F 8$ & $\mathrm{Xq}$ & $\mathrm{L} 1 \mathrm{Ta}$ & $3800 / \mathrm{S}$ & 54 & E14 & - & Southern blotting & [7] \\
\hline$F 8$ & $\mathrm{Xq}$ & L1 preTa & 2300/AS & 77 & E14 & - & Southern blotting & {$[7]$} \\
\hline$F 9$ & $\mathrm{Xq}$ & L1 Ta & $463 / \mathrm{S}$ & 68 & E5 & - & Not specified & [59] \\
\hline$F 9$ & $\mathrm{Xq}$ & $\mathrm{L} 1 \mathrm{Ta}$ & $163 / \mathrm{S}$ & 125 & E7 & - & PCR & {$[60]$} \\
\hline$H B B$ & $11 \mathrm{p}$ & L1 Ta & 6000/AS & 107 & I2 $(+765 ;-85)$ & $\begin{array}{c}\text { Reduced mRNA } \\
\text { expression (15\%) }\end{array}$ & Southern blotting & {$[41,61]$} \\
\hline$R P 2$ & $\mathrm{Xp}$ & L1 Ta & $6000 / \mathrm{S}$ & 64 & $\mathrm{I} 1(+633 ;-15641)$ & $\begin{array}{l}\text { No mRNA } \\
\text { expression }\end{array}$ & Southern blotting & {$[24]$} \\
\hline RPS6KA3 & $\mathrm{Xp}$ & L1 HS & 2800/AS & Yes $^{\mathrm{f}}$ & I3 $(+5177 ;-8)$ & Skipping of E4 & $\begin{array}{c}\text { Initially failed to } \\
\text { amplify exon } 4\end{array}$ & {$[40]$} \\
\hline$A P C$ & $5 q$ & AluYb8 & $278 / S$ & 40 & E15 & - & PCR & {$[62]$} \\
\hline$B C H E$ & $3 q$ & AluYb9 & $289 / \mathrm{S}$ & 38 & E2 & - & Southern blotting & [63] \\
\hline$B R C A 1$ & $17 \mathrm{q}$ & AluS & $286 / \mathrm{S}$ & Yes $^{f}$ & E11 & - & Protein truncation test & {$[21]$} \\
\hline$B R C A 2$ & $13 q$ & AluYc1 & $281 / \mathrm{S}$ & 62 & E22 $(+36 ;-163)$ & Skipping of E22 & PCR & {$[25]$} \\
\hline$B R C A 2$ & $13 q$ & AluYa5 & $285 / \mathrm{S}$ & Yes $^{\mathrm{f}}$ & E3 & Skipping of E3 & Southern blotting & {$[21]$} \\
\hline$B T K$ & $\mathrm{Xq}$ & AluY & -IAS & - & $\mathrm{E} 8$ & - & PCR & {$[64,65]$} \\
\hline$B T K$ & $\mathrm{Xq}$ & AluY & $281 / \mathrm{S}$ & 74 & E9 & - & PCR & {$[15]$} \\
\hline CASR & $3 q$ & AluYa5 & 280/AS & 93 & E7 & - & PCR & {$[66]$} \\
\hline CLCN5 & $\mathrm{Xp}$ & AluYa5 & $281 / \mathrm{S}$ & 50 & E11 & Skipping of E11 & PCR & {$[26,32]$} \\
\hline$C R B 1$ & 1q & AluY & -IAS & 70 & E7 & - & PCR & {$[67]$} \\
\hline EYA1 & $8 \mathrm{q}$ & AluYa5 & 一/AS & $97 ; 31^{\mathrm{g}}$ & E10 & - & Southern blotting & {$[68]$} \\
\hline$F 8$ & $\mathrm{Xq}$ & AluYb9 & 288/AS & 37 & I18 $(+1734 ;-5)$ & Skipping of E19 & PCR & {$[35]$} \\
\hline$F 9$ & $\mathrm{Xq}$ & AluYa5a2 & $244 / \mathrm{S}$ & 78 & E5 & - & Southern blotting & [69] \\
\hline$F 9$ & $\mathrm{Xq}$ & AluYa5a2 & $237 / S$ & 39 & E5 & - & PCR & {$[70]$} \\
\hline F9 & $\mathrm{Xq}$ & $A l u \mathrm{Y}$ & 279/AS & 40 & E8 & - & Not specified & [59] \\
\hline FGFR2 & $10 \mathrm{q}$ & AluYa5 & 283/AS & 69 & I8 $(-2)$ & Skipping of E9 & PCR & {$[36]$} \\
\hline FGFR2 & $10 \mathrm{q}$ & Alu $\mathrm{Yb} 8$ & 288/AS & 47 & E9 & - & PCR & {$[36]$} \\
\hline$G K$ & $\mathrm{Xp}$ & AluYc1 & 241/AS & 74 & I4 (+13629; -42) & See text & PCR & [39] \\
\hline HESX1 & $3 p$ & $A l u Y b 8$ & $288 / \mathrm{S}$ & 30 & E3 & Complex splicing & PCR & [27] \\
\hline$H M B S$ & $11 \mathrm{q}$ & AluYa5 & 279/AS & 39 & E5 $(+32 ;-18)$ & $\begin{array}{l}\text { No mRNA } \\
\text { expression }\end{array}$ & PCR & {$[28]$} \\
\hline$I L 2 R G$ & $\mathrm{Xq}$ & AluYa5 & -IAS & - & I7 $(-17)$ & - & PCR & {$[64,65]$} \\
\hline NF1 & $17 \mathrm{q}$ & AluYa5 & 282/AS & 40 & $\mathrm{I} 40(+134 ;-27)$ & Skipping of E41 & Southern blotting & {$[37]$} \\
\hline SERPING1 & $11 \mathrm{q}$ & AluYc1 & $285 / \mathrm{S}$ & 42 & I6 & - & Not specified & {$[71]$} \\
\hline TNFRSF6 & $10 \mathrm{q}$ & AluYa5 & 281/AS & 33 & I7 $(+1212 ;-50)$ & Skipping of E8 & RT-PCR & {$[38]$} \\
\hline ZFHX1B & $2 q$ & AluYa5 & $281 / \mathrm{S}$ & 93 & E8 & - & PCR & {$[72]$} \\
\hline$A R H$ & $1 \mathrm{p}$ & SVA & $2600 / S$ & 57 & I1 (+687; -9453) & No expression & $\begin{array}{c}\text { Initially failed to } \\
\text { amplify a small } \\
\text { region of intron } 1 \\
\text { in a homozygous } \\
\text { patient }\end{array}$ & {$[50]$} \\
\hline BTK & $\mathrm{Xq}$ & SVA & $491 / \mathrm{S}$ & 74 & E9 $(+51 ;-26)$ & Skipping of E9 & $\begin{array}{c}\text { Initially failed to } \\
\text { amplify E9 by PCR }\end{array}$ & {$[48]$} \\
\hline$F C M D$ & $9 q$ & SVA & $3062 / \mathrm{S}$ & Yes $^{\mathrm{f}}$ & 3'-UTR (see text) & $\begin{array}{l}\text { Nearly no } \\
\text { expression }\end{array}$ & Southern blotting & {$[51]$} \\
\hline SPTA1 & $1 \mathrm{q}$ & SVA & $632 / \mathrm{S}$ & 50 & E5 $(+60 ;-87)$ & Skipping of E5 & RT-PCR & [49] \\
\hline
\end{tabular}


TABLE 1: Continued

\begin{tabular}{|c|c|c|c|c|c|c|c|c|}
\hline \multicolumn{9}{|c|}{ Genomic deletions associated with L1-mediated retrotransposons } \\
\hline$D M D$ & $\mathrm{Xp}$ & $\mathrm{L} 1 \mathrm{Ta}$ & 608/AS ( $\Delta 1 \mathrm{bp})$ & 16 & $\mathrm{E} 44(+145 ;-3)$ & Skipping of E44 & PCR & {$[54]$} \\
\hline FCMD & $9 q$ & $\mathrm{~L} 1 \mathrm{Ta}$ & $1200 / \mathrm{S}(\Delta 6 \mathrm{bp})$ & 59 & I7 $(+2527 ;-24)$ & Complex splicing & Southern blotting & {$[55]$} \\
\hline$A B C D 1$ & $\mathrm{Xq}$ & Alu Yb9 & $98 / \mathrm{S}(\Delta 4726 \mathrm{bp})$ & 20 & I5 & $N A^{\mathrm{h}}$ & $\begin{array}{c}\text { Initially failed to } \\
\text { amplify several } \\
\text { exons by PCR }\end{array}$ & {$[17]$} \\
\hline$A P C$ & $5 q$ & Alu Yb9 & 93/AS ( $\Delta 1599 \mathrm{bp})$ & 60 & E14 & NA & $\begin{array}{c}\text { In vitro synthesized- } \\
\text { protein assay }\end{array}$ & {$[52]$} \\
\hline$F 8$ & $\mathrm{Xq}$ & AluYb8 & 290/AS ( $\Delta 2 \mathrm{bp})$ & 47 & E14 & - & Southern blotting & {$[73]$} \\
\hline SERPINC1 & $1 \mathrm{q}$ & Alu & 6/AS $(\Delta 1444$ bp $)$ & 40 & $\mathrm{I} 3 \mathrm{~b}$ & NA & Southern blotting & {$[53]$} \\
\hline \multicolumn{9}{|c|}{ Genomic deletions associated with only simple poly $(A)$ insertions } \\
\hline$A G A$ & $4 q$ & NA & NA/AS $(\Delta 2076$ bp $)$ & 37 & I8 & NA & RT-PCR & {$[74]$} \\
\hline$B R C A 2$ & $13 q$ & NA & $\mathrm{NA} / \mathrm{S}(\Delta 6212 \mathrm{bp})$ & 35 & I13 & NA & Southern blotting & {$[75]$} \\
\hline COL4A6 & $\mathrm{Xq}$ & NA & $\mathrm{NA} / \mathrm{AS}(\Delta>40 \mathrm{~kb})$ & 70 & $\mathrm{I} 2$ & NA & Southern blotting & {$[76]$} \\
\hline
\end{tabular}

*The entries are presented in the same order as in Table 2 from Chen et al [6] for easy comparison, except for the addition of three simple Alu insertions (BRCA1 [21]; BRCA2 [21]; and HESX1 [27]) that have been reported during the preparation of this review. Data on chromosomal location, inserted element and orientation, insertion size, and length of poly (A) tail were derived from Table 2 in Chen et al [6].

${ }^{a}$ With respect to the sense strand of the disrupted gene. S, sense; AS, antisense. The lengths of the genomic deletions associated with L1-mediated retrotransposons and simple poly (A) insertions are indicated in parentheses.

${ }^{b} \mathrm{I}$, intron; E, exon. When an insertion occurred into an intron/exon and accompanying RNA analysis data were available, the position of the insertion's integration site was indicated in parentheses (+, relative to the first nucleotide of the intron/exon; -, relative to the last nucleotide of the intron/exon).

'Only the effect on the target gene's pre-mRNA splicing and/or mRNA expression was evaluated.

dThe method that initially suggested/identified the mutation at the nucleotide level. PCR indicates all PCR-based techniques using genomic DNA as templates.

${ }^{e}$ Data not available.

${ }^{\text {fPoly }}$ (A) tail present but number of residues not specified.

g97 bp in the affected mother and $31 \mathrm{bp}$ in the affected daughter, respectively.

${ }^{\mathrm{h}}$ Not applicable.

L1-mediated retrotranspositional events that have been associated with genomic deletions $(n=9$; Table 1$)$. All these events probably resulted from L1 endonuclease-dependent retrotranspositional activity because not only have all the inserts integrated at typical L1-endonuclease cleavage sites, but they also possess poly (A) tails (see [6, Tables 1 and 2 and Figure 3]). By contrast, the three L1-derived extra-short inserts (termed "hyphen elements" by Audrézet et al [10]) identified at the junctions of large genomic deletions [1012] did not share the above two hallmark characteristics of L1 endonuclease-dependent retrotranspositional events. These three mutations have therefore been proposed to have arisen via a "repair" process for existing DNA lesions, an L1 endonuclease-independent mechanism [13] that is likely to be qualitatively different from L1 endonuclease-based insertional mutagenesis (see [6, Table 1]).

The above $51 \mathrm{~L} 1$ endonuclease-mediated retrotranspositional events account for $\sim 0.1 \%$ of known mutations ( 52,000 as of April 2005) causing human genetic disease, based upon the data collated in the Human Gene Mutation Database (http://www.hgmd.org/; [14]). The occurrence of L1-mediated simple retrotranspositional events has however long been thought to have been underestimated since large insertions may often be overlooked by routinely used PCR-based mutation detection techniques (eg, $[15,16])$. In this review, we have sought to explore how this mutation detection bias could have operated. To this end, we first manually evaluated the original publications that reported the 51
L1 endonuclease-mediated retrotranspositional events with respect to the mutation detection method(s) that initially suggested/identified the presence of an insertion or deletion at the nucleotide (ie, DNA or RNA) level. The locations of these lesions within the target genes (ie, in the $5^{\prime}$ untranslated regions (UTRs), exons, introns, or $3^{\prime}$-UTRs, resp) were also systematically annotated. Then, in order to assess the likelihood of having underestimated the occurrence of this type of mutational event, we attempted to relate the chromosomal location of the affected genes, as well as the types, sizes, and precise locations of the inserted sequence within the genes, to the mutation detection methods employed (Table 1).

In the context of the analysis of possible mutation detection bias, we excluded, for reasons of simplicity, the following entries from further consideration: (i) the three large genomic deletions that were associated with only simple poly (A) insertions, since the type of L1-mediated retrotransposon involved is unknown (Table 1) and (ii) the SVA simple insertions, owing to their limited number (only 4; Table 1). Our primary focus has therefore been the L1 and Alu insertions, both of which have been frequently found to cause human genetic disease. In addition, we did not consider the 42 simple insertions separately from the 6 genomic deletions associated with L1-mediated retrotransposons, on the basis that all were considered to have resulted from the same L1 endonuclease-mediated insertional mechanism. However, it is important to emphasize that, of the latter 6 cases, three 
TABLE 2: X-chromosome/autosome comparison with respect to gene number, disease genes, known mutations, and retrotranspositional insertion events.

\begin{tabular}{l|c|c|c|c|c|c|c}
\hline & $\begin{array}{c}\text { No. of Alu } \\
\text { insertions causing } \\
\text { genetic disease }\end{array}$ & $\begin{array}{c}\text { No. of L1 direct } \\
\text { insertions causing } \\
\text { genetic disease }\end{array}$ & Size (Mb) & $\begin{array}{c}\text { Known/putative } \\
\text { genes in the } \\
\text { human genome }\end{array}$ & $\begin{array}{c}\text { Diseases/traits } \\
\text { in OMIM }\end{array}$ & $\begin{array}{c}\text { Disease genes } \\
\text { in HGMD }\end{array}$ & $\begin{array}{c}\text { Mutations } \\
\text { in HGMD }^{\mathrm{e}}\end{array}$ \\
\hline A: X chromosome & 11 & 12 & 155 & 1,098 & 895 & 124 & 10010 \\
B: autosomes+Y & 18 & 3 & 3045 & $\sim 39,000$ & 14,977 & 1877 \\
(A/B) \% & 65.1 & 400 & 5.1 & 2.8 & 6.0 & 6.6 & 23.8 \\
\hline
\end{tabular}

a,b Data from [20].

cData from OMIM ( http://www.ncbi.nlm.nih.gov/entrez/query.fcgi?db=OMIM\&itool=toolbar) as of April 2005.

d,e Data from HGMD (http://www.hgmd.org/) as of April 2005.

events were associated with extremely short target gene deletions ( $\triangle 1 \mathrm{bp}$ in $D M D ; \triangle 6 \mathrm{bp}$ in FCMD; and $\triangle 2 \mathrm{bp}$ in F8) yet contain relatively long inserts (Table 1 ); they were thus treated here as simple insertions. By contrast, the three Alu insertions that are associated with large genomic deletions ( $\triangle 4726 \mathrm{bp}$ in $A B C D 1 ; \triangle 1599 \mathrm{bp}$ in $A P C$; and $\triangle 1444 \mathrm{bp}$ in SERPINC1) were treated as simple large genomic deletions since in all cases, the inserted Alu sequences plus the poly (A) tails are rather short (Table 1).

Since a typical Alu sequence is invariably $<290 \mathrm{bp}$ in length and the poly (A) tails associated with L1-mediated retrotransposons are usually $<100 \mathrm{bp}$ (see also [6, Table 4]), the length of an Alu insert plus its poly (A) tail should be $<400$ bp (Table 1). At first sight, it would appear unlikely that those Alu inserts which cause sex-linked disease are going to be significantly underestimated both because X-linked diseases readily come to clinical attention in males and because inserts of $<400 \mathrm{bp}$ into male $\mathrm{X}$ chromosomes are readily identifiable by routine PCR-based methods. Indeed, as is evident from Table 1, only in rare cases have the simple Alu inserts that have become integrated into the $\mathrm{X}$ chromosome been detected by Southern blotting or RT-PCR, and these would also have been amenable to detection by routine PCRbased methods. Whilst an electrophoretic band of larger than the expected size was demonstrated in the cases of Alu insertions when PCR products were examined, failure to PCR amplify several exons was encountered in the case of the $4726 \mathrm{bp}$ deletion involving the $\mathrm{X}$-linked $A B C D 1$ gene [17].

To date, whereas 11 Alu insertions have been identified in $\mathrm{X}$-linked genes as a cause of human genetic disease in male patients, the comparable figure for the autosomes is only 18 (Table 1). Although the X chromosome has been claimed to be a preferred target for retrotransposition $[18,19]$, it is difficult to accept that the observed chromosomal distribution of retrotranspositional mutations reflects the actual distribution since the $\mathrm{X}$ chromosome comprises only $~ 5 \%$ of the human genome [20]. Consequently, it would appear likely that at least a proportion of $A l u$ insertions causing human autosomal disease have been overlooked by routine PCR-based techniques. This could have been due to preferential PCR amplification of the wild-type allele which would have "masked" the Alu insertion mutant allele, an example being the failure to detect two Alu insertions by routinely used methods [21].
L1 direct inserts are usually much longer than Alu inserts (Table 1). Although, in principle, the presence of large inserts in X-linked genes in males might be initially suggested by the failure to PCR amplify the exon(s) under investigation (eg, as in the case of the $6017 \mathrm{bp} \mathrm{L1}$ insertion in the CHM gene [22]), most of the L1 direct insertions listed in Table 1 were reported to have been initially identified by RT-PCR or Southern blotting. Given the extensive efforts devoted to screening for X-linked disease (note particularly the identification of two inserts that had become integrated into deep intronic regions (CYBB [23]; RP2 [24])), we surmise that the current figure $(n=12)$ of L1 direct inserts into the X chromosome may approach complete ascertainment. In this context, it is noteworthy that with respect to the insertions causing human X-linked disease, the number of reported L1 direct insertions $(n=12)$ is approximately the same as that of reported Alu insertions into X-linked genes $(n=11)$. However, by comparison with disease-causing Alu insertions that have become integrated within autosomal genes $(n=18)$, an apparent paucity of disease-causing autosomal L1 direct inserts $(n=3)$ is evident (Table 1$)$. The reason for this finding may be quite simple: the longer the inserts are, the more easily will they be missed by routine PCR-based techniques in the presence of a wild-type allele. It is therefore not unreasonable to conclude that the occurrence of L1 direct insertions causing autosomal disease has probably been significantly underestimated.

To obtain further insights into this issue, we examined the above finding in the context of a multiple pairwise comparison (Table 2). This revealed that, in general, mutations in $\mathrm{X}$-linked genes are significantly over-represented in HGMD by comparison with both the proportion of X-linked to non-X-linked genes in HGMD (4-fold; $p<0.0001$ ), and the proportion of $\mathrm{X}$-linked to non-X-linked genes in the genome as a whole (8-fold; $p<0.0001$ ). This could be due to a number of different factors including (i) the $\mathrm{X}$ chromosome bearing a slightly higher proportion of genes that are "disease genes" than other chromosomes, (ii) Xlinked disease may come to clinical attention more readily than autosomal disease since recessive mutations will become manifest in hemizygous males, (iii) hemizygous insertional mutations on the X-chromosome may, using currently used mutation detection techniques, be more readily detectable than heterozygous/compound heterozygous 
insertional mutations on the autosomes (due to the inherent limitations of PCR/“masking" of the mutant allele by the wild-type allele), (iv) greater effort may have been expended, historically, in identifying the genes and characterizing the mutational spectra underlying X-linked disease, and (v) the X-chromosome may represent a preferred retrotranspositional target as compared to other chromosomes. In reality, a combination of all these different factors has probably been operating. These considerations are also likely to apply to retrotranspositional insertions and may together account for the discrepancy in the observed prevalence of insertions into the $\mathrm{X}$-chromosome as compared with the autosomes.

\section{MULTIPLE MECHANISMS OF TARGET GENE DISRUPTION}

We also systematically surveyed the original publications that reported the $51 \mathrm{~L} 1$ endonuclease-mediated retrotranspositional events with respect to the evidence presented for functional disruption of the target genes at the RNA level (ie, aberrant splicing and/or decreased mRNA expression). The information obtained was further evaluated in the context of the size, orientation, and integration sites of the inserts wherever possible and appropriate (Table 1).

\section{Simple insertions}

\section{Alu insertions}

Of the 18 simple Alu insertions that integrated within coding regions, only five were informative with respect to the functional disruption of the target genes at the RNA level (BRCA2 [25]; BRCA2 [21]; CLCN5 [26], HESX1 [27]; HMBS [28]). This was in sharp contrast to the 7 simple Alu insertions that are known to have become integrated into intronic regions, 5 of which were informative. The probable reason for this phenomenon is that $A l u$ insertions into coding regions will invariably lead to the loss of a functional protein product, irrespective of the precise point at which the gene expression pathway has been disrupted.

The Alu insertion into exon 22 of the BRCA2 gene resulted in the skipping of the exon involved through "some unknown mechanism" [25]. With hindsight, this insertion, which integrated fairly deeply into the exon involved (36 bp after the first nucleotide and $163 \mathrm{bp}$ before the last nucleotide of exon 22; Table 1), could have disrupted cis-splicing elements such as an exon splicing enhancer or/and could have interacted with trans-acting cellular splicing factors, resulting in the "silencing" of the upstream constitutional splice acceptor site (for reviews, see [29-31]). Consistent with this postulate, the Alu insertion in the CLCN5 gene [32] was recently suggested to interfere with splicing regulatory elements, resulting in exon 11 skipping [26]. However, this is certainly not the case for the Alu insertion into exon 5 of the $H M B S$ gene: both in vitro expression studies and in vivo RT-PCR analyses demonstrated that the mutant HMBS allele was not expressed at the RNA level [28]. Of the various possible mechanisms proposed by the original authors, we favour nonsense-mediated mRNA decay $[33,34]$.

All 5 informative Alu intronic insertions are located nearer to the downstream exons than to the preceding exons. Consequently, most of them $(n=4)$ were found to cause skipping of the downstream exons: whilst two most likely affect the correct recognition of the splice acceptor sites ( F8 [35]; FGFR2 [36]), the other two may affect the branch site that is usually located very close to the end of the intron (NF1 [37]; TNFRSF6 [38]). The remaining intronic insertion (GK [39]) was, however, reported not to "cause any deletions, duplications, premature stop codons, or frameshifts in the individual with benign glycerol kinase deficiency, as determined by RT-PCR (data not shown).” This notwithstanding, since no other mutations were present within the coding regions and intron-exon boundaries of the gene, and since the Alu insertion does not represent a polymorphism, this insertion was concluded to be indeed disease-causing [39]. Although we concur with this conclusion, we nevertheless feel that the functional consequence(s) of the Alu insertion may have been overlooked. In this regard, it is worth pointing out that the patient's radiochemically measured GK activity was $32 \%$ (ie, not a complete loss) that of the mean normal control [39]. It is therefore possible that the Alu insertion did not completely disrupt normal pre-mRNA splicing. However, in the RT-PCR analysis, the aberrantly spliced transcripts may have been unstable and could thus have been "masked" by correctly spliced stable transcripts.

\section{L1 insertions}

As with the Alu simple insertions, only one of the $8 \mathrm{~L} 1$ simple insertions in coding regions was informative with respect to target gene disruption; it caused the skipping of the exon involved [22], probably through a similar mechanism to the above-discussed Alu insertion into the BRCA2 gene [25]. By contrast, all 4 intronic insertions were informative: whilst two insertions were associated with either the skipping of a single exon (RPS6KA3 [40]) or an extremely complex splicing pattern $(C Y B B[23])$, the other two insertions resulted in a significant, or even complete, loss of the mRNA transcript (HBB [41]; RP2 [24]). The latter two examples will now be discussed in detail in the light of a recent report [42].

Both L1 RNA and open-reading-frame-2 (ORF2) protein are very difficult to detect in mammalian cells, suggesting a mammalian-specific mechanism for negatively regulating L1 expression (see [42] and references therein). Indeed, the A-rich sense strand of an active human L1 element (ie, LINE-1.3; [43]), containing many canonical $(n=19)$ and noncanonical $(n=141)$ polyadenylation signals, has been noted to be prone to generate truncated transcripts by premature polyadenylation, at least under in vitro conditions [44]. However, using a different cell culture assay, Han et al [42] have shown that poor expression of the ORF2 protein is mainly due to the inability of RNA polymerase to elongate efficiently through L1 coding sequences (despite a minor contribution from premature polyadenylation). Moreover, these authors have demonstrated that an ORF2 sequence, 
when placed in the antisense orientation, inhibits transcription primarily by promoting premature polyadenylation. Based upon these observations, Han et al [42] predicted that L1 elements which have become inserted into introns could attenuate the expression of target genes either by premature truncation of RNA (in the antisense orientation) or by promoting transcriptional elongation (in the sense orientation), both mechanisms resulting in the decreased production of full-length pre-mRNA. Consistent with this postulate, highly expressed genes were found to contain relatively small amounts of L1 sequence, whereas poorly expressed genes contained large amounts [42].

In particular, the full-length de novo L1 insertion into intron 1 of the RP2 gene that is associated with the complete loss of RP2 mRNA synthesis [24] was cited by Han et al [42] as an example to support their thesis. As is evident from Table 1, the L1 insert in the $H B B$ gene [41] shares remarkable similarities with that found in the RP2 gene [24]: both are full-length and both became integrated within introns. However, whereas the full-length RP2 L1 insertion was in the sense orientation and resulted in the complete loss of gene expression, the full-length $H B B$ L1 insertion was in the antisense orientation and the amount of mRNA transcribed from the affected allele was reduced to $30 \%$ of normal (the mRNA transcripts from the affected and unaffected alleles were distinguishable by a codon 2 polymorphism and no splicing variants were detected [41]). This concurs with the in vitro finding that "inserting ORF2 in the antisense orientation produced a similar, but less potent, decrease in full-length RNA" [42]. Thus, the $H B B$ insertion may serve as an additional example of an insertion that is consistent with the proposal that the insertion of L1 elements into a target gene's introns can significantly alter the expression of that gene [42].

The above notwithstanding, it would appear unlikely that the significantly $5^{\prime}$-truncated L1 insert (only $530 \mathrm{bp}$ ) in the $D M D$ gene [45] caused the complete loss of the muscle (M) isoform of dystrophin through inhibition of transcriptional elongation and/or premature polyadenylation; this conclusion is based upon the in vitro observation that the level of reporter RNA expression was inversely correlated with the length of transfected L1 ORF2 (see [42, Figure 3]). Indeed, this short insert, which had integrated just $28 \mathrm{bp}$ upstream of the ATG codon initiating translation of the M isoform encoded by the dystrophin $(D M D)$ gene, must have affected transcriptional initiation and/or regulation. Although the expression of the $\mathrm{M}$ isoform was completely abolished, there were compensatory increases in the expression of the nonmuscle B (brain) and CP (cerebellar Purkinje) isoforms in the patient's skeletal muscle $[45,46]$. (The M, B, and CP isoforms are generally considered to be functionally homologous. However, the transcripts encoding these isoforms contain a unique first exon and are expressed from different, tissue-specific promoters, see [47] and references therein.)

\section{SVA insertions}

Of the four SVA insertions (Table 1), two were inserted into exons causing the skipping of the exons involved (BTK [48];
SPTA1 [49]), whereas the other two were reported to be associated with virtually undetectable mRNA expression $(A R H$ [50]; FCMD [51]). In the case of the ARH mutation, "although no mRNA was detectable by Northern blotting, small amounts of cDNA could be amplified using RT-PCR" [50]. Similarly, "the transcript of this (FCMD) gene was nearly undetectable in FCMD patients who carried the insertion homozygously, and significantly lower than normal in patients heterozygous for the insertion and another mutation haplotype" [51]. As previously discussed [6], although SVA elements are relatively poorly characterized, they are composed of highly repetitive sequences (for a detailed sequence description, see [51]; refer also to [50, Figure 2]). Importantly, both SVA insertions are rather long (2600 and $3062 \mathrm{bp}$, resp). Moreover, the SVA insertion in ARH [50] is very similar to the L1 insertion in RP2 [24] in the following respects: both were in the sense orientation and both had been inserted into the first introns of their respective genes in comparable locations (Table 1). Thus, it is tempting to speculate that the 2600 bp SVA insert may also compromise transcriptional elongation resulting in an undetectable level of mRNA (even although it is C-rich, cf L1 which is A-rich).

That the 3062 bp SVA element had been inserted into the $3^{\prime}$-UTR of the FCMD gene [51] effectively serves to exclude a possible effect on transcriptional initiation. It is also pertinent to note that the normal FCMD transcript comprises a long 3'-UTR of $5952 \mathrm{bp}$; the SVA integration site is $4375 \mathrm{bp}$ downstream of the TGA translational termination codon and $1454 \mathrm{bp}$ upstream of the poly (A) addition signal sequence. Thus, it is very likely that the 3062 bp SVA insertion (in sense orientation) may either inhibit transcriptional elongation or cause abnormal polyadenylation resulting in the complete loss of gene expression.

\section{Genomic deletions associated with L1-mediated retrotranspositional events}

In the 6 cases associated with large target gene deletions (ie, the 3 events associated with L1-mediated retrotransposons (ABCD1 [17]; APC [52]; SERPINC1 [53]) plus the 3 events associated with only a simple poly (A) tail (Table 1)), the role played by L1-mediated short insertions in the functional disruption of the target genes cannot be independently assessed. Of the three events associated with extremely short genomic deletions, only two are informative: whilst the $608 \mathrm{bp} \mathrm{L1}$ insertion in exon 44 of the DMD gene caused the skipping of the exon involved [54], the $1200 \mathrm{bp} \mathrm{L1}$ insertion into intron 7 of the FCMD gene yielded a complex splicing pattern including the skipping of exons 7 and 8, the skipping of only exon 7 , and the skipping of exons 7,8 , and 9 , respectively [55].

\section{CONCLUSIONS}

Mutation detection bias is a complex issue. This notwithstanding, our analysis has suggested that at least two factors (namely, clinical selection and the choice of mutation detection techniques) may have contributed to a significant bias in 
detecting L1-mediated retrotranspositional events that cause human genetic disease. Although there is a general tendency for autosomal L1-mediated insertions to be overlooked, autosomal L1 direct insertions appear likely to be the most seriously underestimated owing to their unusually large size. In particular, given the two examples of L1 direct inserts that have integrated within deep intronic regions $(C Y B B$ [23]; RP2 [24]), it would appear that methods other than PCR-based techniques (eg, RT-PCR and Southern blotting) should be employed whenever necessary and possible, with a view to maximizing the mutation detection rate.

Our analysis has also demonstrated that the mechanisms underlying the functional disruption of target genes by L1mediated retrotranspositional events are dependent on several factors such as the type of insertion, the precise locations of the inserted sequences within the target gene regions, the length of the inserted sequences, and perhaps also their orientation. Thus, an Alu insert might not be capable of efficiently inhibiting transcriptional elongation owing to its small size. Moreover, inserts that have integrated within $5^{\prime}$ - or $3^{\prime}$-UTRs would be likely to affect the target genes differently from those that have integrated within coding or intronic regions. Further, the unique examples of full-length L1 inserts integrated into intronic regions ( $H B B$ [41]; RP2 [24]) suggest that both the length and orientation of L1 inserts may be important in the context of transcriptional inhibition. This notwithstanding, the precise mechanisms underlying certain insertions, for example, the large SVA insert in the deep intronic region in the $A R H$ gene [50] still remains to be clarified.

\section{ACKNOWLEDGMENTS}

We are grateful to Peter Stenson (Cardiff, UK) for providing HGMD data and to Angus Clarke (Cardiff, UK) for helpful discussions about the possible causes of mutation detection bias. Jian-Min Chen is a Visiting Professor of genetics supported by the Ministère de la Jeunesse, de l'Éducation Nationale et de la Recherche, France. This work was supported by the Institut National de la Santé et de la Recherche Médicale (INSERM), France.

\section{REFERENCES}

[1] Lander ES, Linton LM, Birren B, et al. Initial sequencing and analysis of the human genome. Nature. 2001;409(6822):860921.

[2] Brouha B, Schustak J, Badge RM, et al. Hot L1s account for the bulk of retrotransposition in the human population. Proceedings of the National Academy of Sciences of the United States of America. 2003;100(9):5280-5285.

[3] Luan DD, Korman MH, Jakubczak JL, Eickbush TH. Reverse transcription of R2Bm RNA is primed by a nick at the chromosomal target site: a mechanism for non-LTR retrotransposition. Cell. 1993;72(4):595-605.

[4] Feng Q, Moran JV, Kazazian HH Jr, Boeke JD. Human L1 retrotransposon encodes a conserved endonuclease required for retrotransposition. Cell. 1996;87(5):905-916.
[5] Moran JV, Holmes SE, Naas TP, DeBerardinis RJ, Boeke JD, Kazazian HH Jr. High frequency retrotransposition in cultured mammalian cells. Cell. 1996;87(5):917-927.

[6] Chen J-M, Stenson PD, Cooper DN, Férec C. A systematic analysis of LINE-1 endonuclease-dependent retrotranspositional events causing human genetic disease. Human Genetics. 2005;117(5):411-427.

[7] Kazazian HH Jr, Wong C, Youssoufian H, Scott AF, Phillips DG, Antonarakis SE. Haemophilia A resulting from de novo insertion of L1 sequences represents a novel mechanism for mutation in man. Nature. 1988;332(6160):164-166.

[8] Gilbert N, Lutz-Prigge S, Moran JV. Genomic deletions created upon LINE-1 retrotransposition. Cell. 2002;110(3):315-325.

[9] Symer DE, Connelly C, Szak ST, et al. Human 11 retrotransposition is associated with genetic instability in vivo. Cell. 2002;110(3):327-338.

[10] Audrézet M-P, Chen J-M, Raguénès $O$, et al. Genomic rearrangements in the CFTR gene: extensive allelic heterogeneity and diverse mutational mechanisms. Human Mutation. 2004;23(4):343-357.

[11] Mager DL, Henthorn PS, Smithies O. A Chinese ${ }^{G} \gamma^{+}\left({ }^{A} \gamma \delta \beta\right)^{0}$ thalassemia deletion: comparison to other deletions in the human $\beta$-globin gene cluster and sequence analysis of the breakpoints. Nucleic Acids Research. 1985;13(18):6559-6575.

[12] Van de Water N, Williams R, Ockelford P, Browett P. A $20.7 \mathrm{~kb}$ deletion within the factor VIII gene associated with LINE-1 element insertion. Thrombosis and Haemostasis. 1998;79(5):938-942.

[13] Morrish TA, Gilbert N, Myers JS, et al. DNA repair mediated by endonuclease-independent LINE-1 retrotransposition. $\mathrm{Na}$ ture Genetics. 2002;31(2):159-165.

[14] Stenson PD, Ball EV, Mort M, et al. Human Gene Mutation Database (HGMD): 2003 update. Human Mutation. 2003;21(6):577-581.

[15] Conley ME, Partain JD, Norland SM, Shurtleff SA, Kazazian $\mathrm{HH}$ Jr. Two independent retrotransposon insertions at the same site within the coding region of BTK. Human Mutation. 2005;25(3):324-325.

[16] Kazazian HH Jr. An estimated frequency of endogenous insertional mutations in humans. Nature Genetics. 1999;22(2):130.

[17] Kutsche K, Ressler B, Katzera HG, et al. Characterization of breakpoint sequences of five rearrangements in L1CAM and ABCD1 (ALD) genes. Human Mutation. 2002;19(5):526-535.

[18] Emerson JJ, Kaessmann H, Betran E, Long M. Extensive gene traffic on the mammalian $\mathrm{X}$ chromosome. Science. 2004;303(5657):537-540.

[19] Khil PP, Oliver B, Camerini-Otero RD. X for intersection: retrotransposition both on and off the $\mathrm{X}$ chromosome is more frequent. Trends in Genetics. 2005;21(1):3-7.

[20] Ross MT, Grafham DV, Coffey AJ, et al. The DNA sequence of the human X chromosome. Nature. 2005;434(7031):325-337.

[21] Teugels E, De Brakeleer S, Goelen G, Lissens W, Sermijn E, De Greve J. De novo Alu element insertions targeted to a sequence common to the BRCA1 and BRCA2 genes. Human Mutation. 2005;26(3):284.

[22] van den Hurk JA, van de Pol DJ, Wissinger B, et al. Novel types of mutation in the choroideremia (CHM) gene: a full-length L1 insertion and an intronic mutation activating a cryptic exon. Human Genetics. 2003;113(3):268-275.

[23] Meischl C, de Boer M, Åhlin A, Roos D. A new exon created by intronic insertion of a rearranged LINE-1 element as the cause 
of chronic granulomatous disease. European Journal of Human Genetics. 2000;8(9):697-703.

[24] Schwahn U, Lenzner S, Dong J, et al. Positional cloning of the gene for X-linked retinitis pigmentosa 2. Nature Genetics. 1998;19(4):327-332.

[25] Miki Y, Katagiri T, Kasumi F, Yoshimoto T, Nakamura Y. Mutation analysis in the BRCA2 gene in primary breast cancers. Nature Genetics. 1996;13(2):245-247.

[26] Claverie-Martín F, Flores C, Antón-Gamero M, GonzálezAcosta H, García-Nieto V. The Alu insertion in the CLCN5 gene of a patient with Dent's disease leads to exon 11 skipping. Journal of Human Genetics. 2005;50(7):370-374.

[27] Sobrier M-L, Netchine I, Heinrichs C, et al. Alu-element insertion in the homeodomain of HESX1 and aplasia of the anterior pituitary. Human Mutation. 2005;25(5):503.

[28] Mustajoki S, Ahola H, Mustajoki P, Kauppinen R. Insertion of Alu element responsible for acute intermittent porphyria. Human Mutation. 1999;13(6):431-438.

[29] Blencowe BJ. Exonic splicing enhancers: mechanism of action, diversity and role in human genetic diseases. Trends in Biochemical Sciences. 2000;25(3):106-110.

[30] Faustino NA, Cooper TA. Pre-mRNA splicing and human disease. Genes \& Development. 2003;17(4):419-437.

[31] Zheng ZM. Regulation of alternative RNA splicing by exon definition and exon sequences in viral and mammalian gene expression. Journal of Biomedical Science. 2004;11(3):278-294.

[32] Claverie-Martín F, González-Acosta H, Flores C, AntónGamero M, García-Nieto V. De novo insertion of an Alu sequence in the coding region of the CLCN5 gene results in Dent's disease. Human Genetics. 2003;113(6):480-485.

[33] Baker KE, Parker R. Nonsense-mediated mRNA decay: terminating erroneous gene expression. Current Opinion in Cell Biology. 2004;16(3):293-299.

[34] Maquat LE. Nonsense-mediated mRNA decay: splicing, translation and mRNP dynamics. Nature Reviews Molecular Cell Biology. 2004;5(2):89-99.

[35] Ganguly A, Dunbar T, Chen P, Godmilow L, Ganguly T. Exon skipping caused by an intronic insertion of a young Alu Yb9 element leads to severe hemophilia A. Human Genetics. 2003;113(4):348-352.

[36] Oldridge M, Zackai EH, McDonald-McGinn DM, et al. De novo alu-element insertions in FGFR2 identify a distinct pathological basis for Apert syndrome. The American Journal of Human Genetics. 1999;64(2):446-461.

[37] Wallace MR, Andersen LB, Saulino AM, Gregory PE, Glover TW, Collins FS. A de novo Alu insertion results in neurofibromatosis type 1. Nature. 1991;353(6347):864-866.

[38] Tighe PJ, Stevens SE, Dempsey S, Le Deist F, Rieux-Laucat F, Edgar JD. Inactivation of the Fas gene by Alu insertion: retrotransposition in an intron causing splicing variation and autoimmune lymphoproliferative syndrome. Genes \& Immunity. 2002;3(suppl 1):S66-S70.

[39] Zhang Y-H, Dipple KM, Vilain E, et al. AluY insertion (IVS452ins316alu) in the glycerol kinase gene from an individual with benign glycerol kinase deficiency. Human Mutation. 2000;15(4):316-323.

[40] Martínez-Garay I, Ballesta MJ, Oltra S, et al. Intronic L1 insertion and F268S, novel mutations in RPS6KA3 (RSK2) causing Coffin-Lowry syndrome. Clinical Genetics. 2003;64(6):491496.
[41] Divoky V, Indrak K, Mrug M, Brabec V, Huisman THJ, Prchal JT. A novel mechanism of $\beta$ thalassemia: the insertion of L1 retrotransposable element into $\beta$ globin IVS II. Blood. 1996; 88(suppl 1):148a.

[42] Han JS, Szak ST, Boeke JD. Transcriptional disruption by the L1 retrotransposon and implications for mammalian transcriptomes. Nature. 2004;429(6989):268-274.

[43] Dombroski BA, Mathias SL, Nanthakumar E, Scott AF, Kazazian HH Jr. Isolation of an active human transposable element. Science. 1991;254(5039):1805-1808.

[44] Perepelitsa-Belancio V, Deininger P. RNA truncation by premature polyadenylation attenuates human mobile element activity. Nature Genetics. 2003;35(4):363-366.

[45] Yoshida K, Nakamura A, Yazaki M, Ikeda S, Takeda S. Insertional mutation by transposable element, L1, in the DMD gene results in X-linked dilated cardiomyopathy. Human Molecular Genetics. 1998;7(7):1129-1132.

[46] Nakamura A, Ikeda S, Yazaki M, et al. Up-regulation of the brain and Purkinje-cell forms of dystrophin transcripts, in Becker muscular dystrophy. The American Journal of Human Genetics. 1997;60(6):1555-1558.

[47] Bastianutto C, Bestard JA, Lahnakoski K, et al. Dystrophin muscle enhancer 1 is implicated in the activation of nonmuscle isoforms in the skeletal muscle of patients with $\mathrm{X}$ linked dilated cardiomyopathy. Human Molecular Genetics. 2001;10(23):2627-2635.

[48] Rohrer J, Minegishi Y, Richter D, Eguiguren J, Conley ME. Unusual mutations in Btk: an insertion, a duplication, an inversion, and four large deletions. Clinical Immunology. 1999; 90(1):28-37.

[49] Hassoun H, Coetzer TL, Vassiliadis JN, et al. A novel mobile element inserted in the alpha spectrin gene: spectrin dayton. A truncated alpha spectrin associated with hereditary elliptocytosis. The Journal of Clinical Investigation. 1994;94(2):643648.

[50] Wilund KR, Yi M, Campagna F, et al. Molecular mechanisms of autosomal recessive hypercholesterolemia. Human Molecular Genetics. 2002;11(24):3019-3030.

[51] Kobayashi K, Nakahori Y, Miyake M, et al. An ancient retrotransposal insertion causes Fukuyama-type congenital muscular dystrophy. Nature. 1998;394(6691):388-392.

[52] Su LK, Steinbach G, Sawyer JC, Hindi M, Ward PA, Lynch PM. Genomic rearrangements of the APC tumor-suppressor gene in familial adenomatous polyposis. Human Genetics. 2000;106(1):101-107.

[53] Beauchamp NJ, Makris M, Preston FE, Peake IR, Daly ME. Major structural defects in the antithrombin gene in four families with type I antithrombin deficiency-Partial/complete deletions and rearrangement of the antithrombin gene. Thrombosis and Haemostasis. 2000;83(5):715-721.

[54] Narita N, Nishio H, Kitoh Y, et al. Insertion of a $5^{\prime}$ truncated L1 element into the $3^{\prime}$ end of exon 44 of the dystrophin gene resulted in skipping of the exon during splicing in a case of Duchenne muscular dystrophy. The Journal of Clinical Investigation. 1993;91(5):1862-1867.

[55] Kondo-Iida E, Kobayashi K, Watanabe M, et al. Novel mutations and genotype-phenotype relationships in 107 families with Fukuyama-type congenital muscular dystrophy (FCMD). Human Molecular Genetics. 1999;8(12):2303-2309.

[56] Miki Y, Nishisho I, Horii A, et al. Disruption of the APC gene by a retrotransposal insertion of $\mathrm{L} 1$ sequence in a colon cancer. Cancer Research. 1992;52(3):643-645. 
[57] Brouha B, Meischl C, Ostertag EM, et al. Evidence consistent with human $\mathrm{L} 1$ retrotransposition in maternal meiosis I. The American Journal of Human Genetics. 2002;71(2):327-336.

[58] Holmes SE, Dombroski BA, Krebs CM, Boehm CD, Kazazian $\mathrm{HH}$ Jr. A new retrotransposable human L1 element from the LRE2 locus on chromosome 1q produces a chimaeric insertion. Nature Genetics. 1994;7(2):143-148.

[59] Li X, Scaringe WA, Hill KA, et al. Frequency of recent retrotransposition events in the human factor IX gene. Human $\mathrm{Mu}$ tation. 2001;17(6):511-519.

[60] Mukherjee S, Mukhopadhyay A, Banerjee D, Chandak GR, Ray K. Molecular pathology of haemophilia B: identification of five novel mutations including a LINE 1 insertion in Indian patients. Haemophilia. 2004;10(3):259-263.

[61] Kimberland ML, Divoky V, Prchal J, Schwahn U, Berger W, Kazazian HH Jr. Full-length human L1 insertions retain the capacity for high frequency retrotransposition in cultured cells. Human Molecular Genetics. 1999;8(8):1557-1560.

[62] Halling KC, Lazzaro CR, Honchel R, et al. Hereditary desmoid disease in a family with a germline $A l u$ I repeat mutation of the APC gene. Human Heredity. 1999;49(2):97-102.

[63] Muratani K, Hada T, Yamamoto Y, et al. Inactivation of the cholinesterase gene by Alu insertion: possible mechanism for human gene transposition. Proceedings of the National Academy of Sciences of the United States of America. 1991;88 (24):11315-11319.

[64] Lester T, McMahon C, Van Regemorter N, Jones A, Genet S. $\mathrm{X}$-linked immunodeficiency caused by insertion of Alu repeat sequences. Journal of Medical Genetics. 1997;34(suppl 1):S81.

[65] Ostertag EM, Kazazian HH Jr. Biology of mammalian L1 retrotransposons. Annual Review of Genetics. 2001;35:501538.

[66] Janicic N, Pausova Z, Cole DE, Hendy GN. Insertion of an Alu sequence in the $\mathrm{Ca}^{2+}$-sensing receptor gene in familial hypocalciuric hypercalcemia and neonatal severe hyperparathyroidism. The American Journal of Human Genetics. 1995;56(4):880-886.

[67] den Hollander AI, ten Brink JB, de Kok YJ, et al. Mutations in a human homologue of Drosophila crumbs cause retinitis pigmentosa (RP12). Nature Genetics. 1999;23(2):217-221.

[68] Abdelhak S, Kalatzis V, Heilig R, et al. Clustering of mutations responsible for branchio-oto-renal (BOR) syndrome in the eyes absent homologous region (eyaHR) of EYA1. Human Molecular Genetics. 1997;6(13):2247-2255.

[69] Vidaud D, Vidaud M, Bahnak BR, et al. Haemophilia B due to a de novo insertion of a human-specific Alu subfamily member within the coding region of the factor IX gene. European Journal of Human Genetics. 1993;1(1):30-36.

[70] Wulff K, Gazda H, Schroder W, Robicka-Milewska R, Herrmann FH. Identification of a novel large F9 gene mutationAn insertion of an Alu repeated DNA element in exon e of the factor 9 gene. Human Mutation. 2000;15(3):299.

[71] Stoppa-Lyonnet D, Carter PE, Meo T, Tosi M. Clusters of intragenic Alu repeats predispose the human $\mathrm{Cl}$ inhibitor locus to deleterious rearrangements. Proceedings of the National Academy of Sciences of the United States of America. 1990;87 (4):1551-1555.

[72] Ishihara N, Yamada K, Yamada Y, et al. Clinical and molecular analysis of Mowat-Wilson syndrome associated with $Z F H X 1 B$ mutations and deletions at 2q22-q24.1. Journal of Medical Genetics. 2004;41(5):387-393.
[73] Sukarova E, Dimovski AJ, Tchacarova P, Petkov GH, Efremov GD. An Alu insert as the cause of a severe form of hemophilia A. Acta Haematologica. 2001;106(3):126-129.

[74] Jalanko A, Manninen T, Peltonen L. Deletion of the C-terminal end of aspartylglucosaminidase resulting in a lysosomal accumulation disease: evidence for a unique genomic rearrangement. Human Molecular Genetics. 1995;4(3):435-441.

[75] Wang T, Lerer I, Gueta Z, et al. A deletion/insertion mutation in the BRCA2 gene in a breast cancer family: a possible role of the Alu-polyA tail in the evolution of the deletion. Genes, Chromosomes and Cancer. 2001;31(1):91-95.

[76] Segal Y, Peissel B, Renieri A, et al. LINE-1 elements at the sites of molecular rearrangements in Alport syndrome-diffuse leiomyomatosis. The American Journal of Human Genetics. 1999;64(1):62-69. 

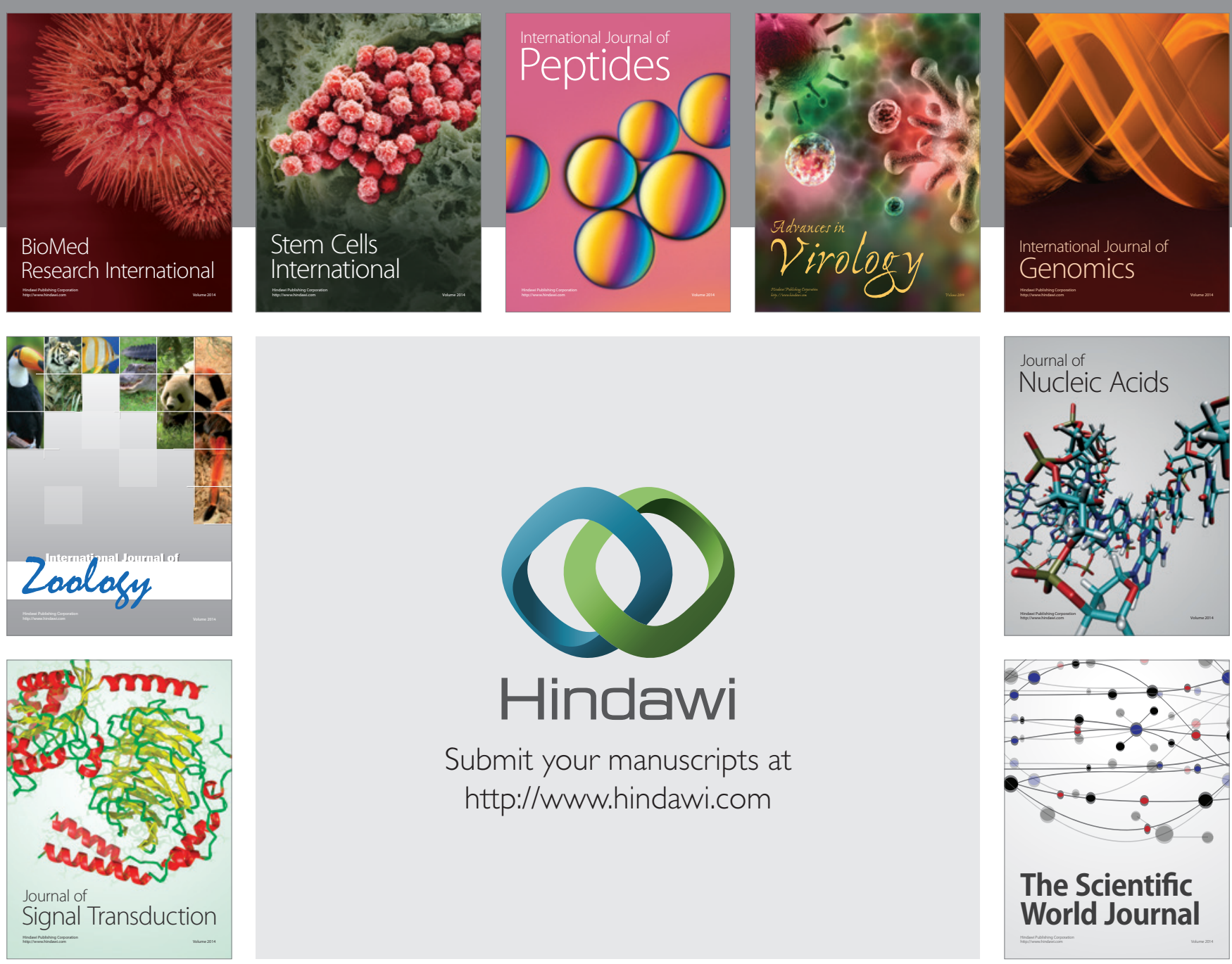

Submit your manuscripts at

http://www.hindawi.com
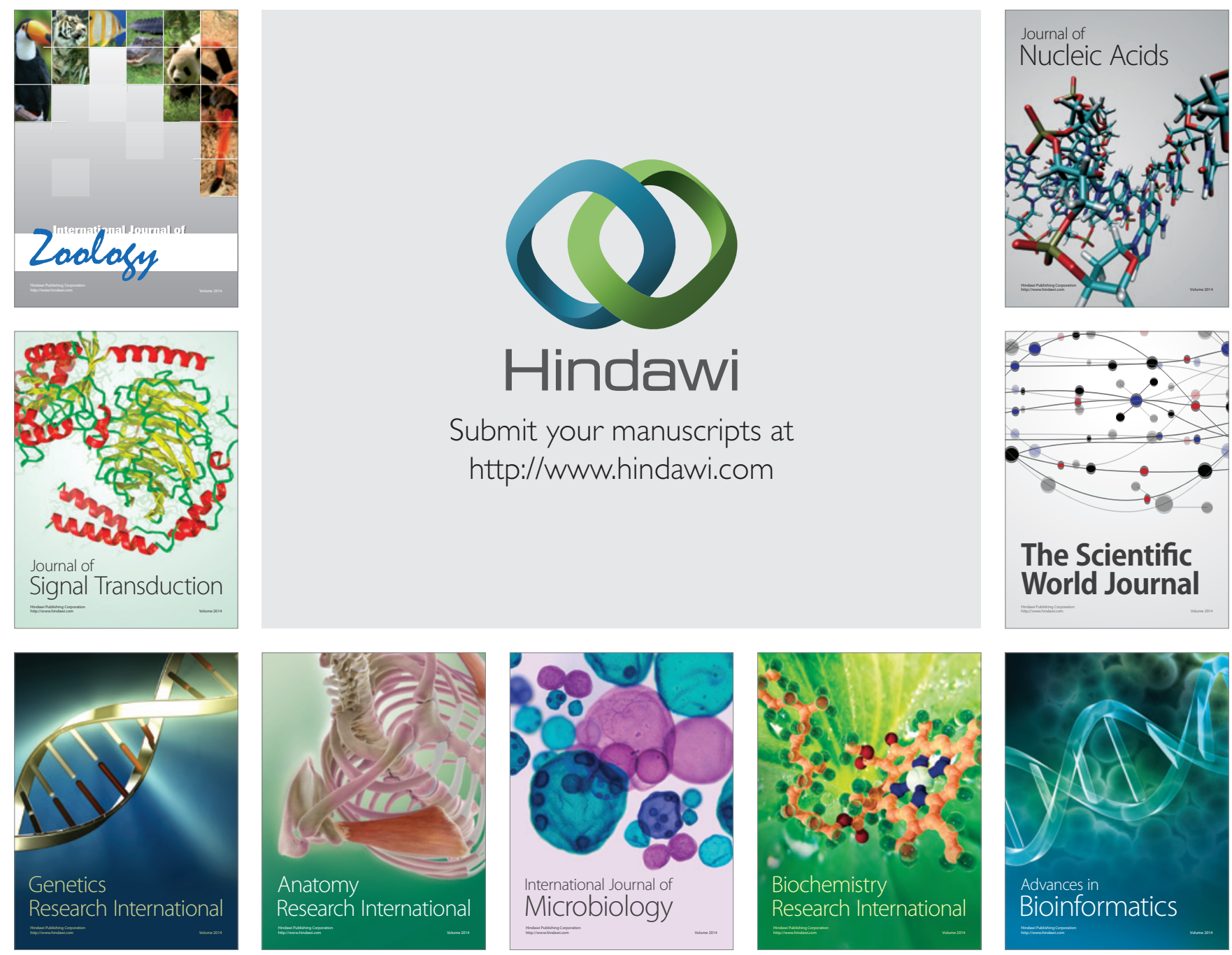

The Scientific World Journal
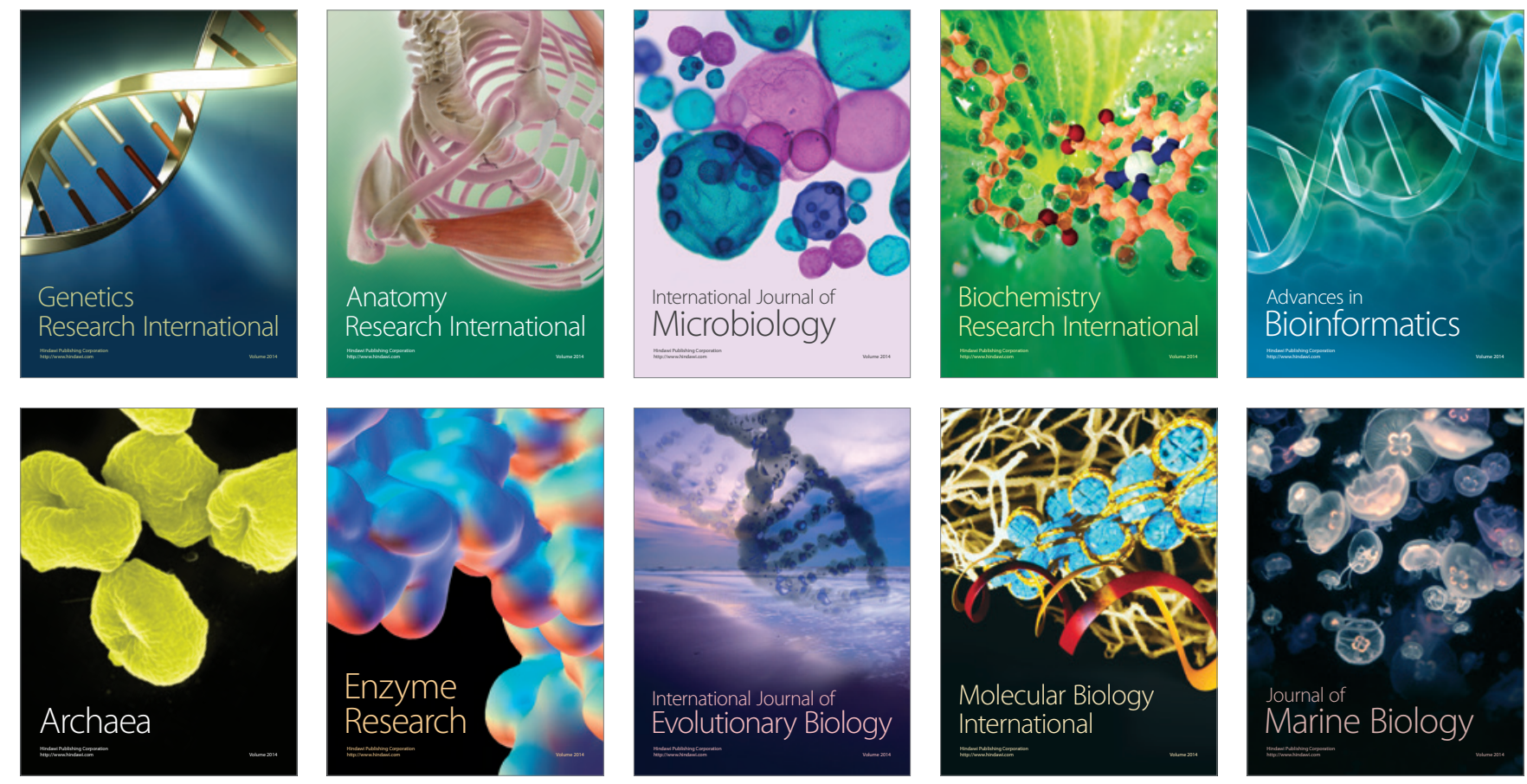